\title{
Study of VOCs release during drying of plantation-grown Pinus sylvestris and naturally grown Russian Pinus sy/vestris
}

\author{
Yulin Shen ${ }^{1 \dagger}$, Xiaotao Zhang ${ }^{2 \dagger}$, Qin He ${ }^{1 \dagger}$, Xia Wang ${ }^{2}$, Zhe Wang ${ }^{1}$, Junli Yang ${ }^{4}$, Zhangjing Chen ${ }^{3}$, Jianfang Yu ${ }^{1 *}$, \\ Huaqiong Duo ${ }^{1 *}$ and Ximing Wang ${ }^{1 *}$
}

\begin{abstract}
A study was carried out to investigate the release of volatile organic compounds (VOCs) during drying of plantation Pinus sylvestris grown in China and naturally grown Pinus sylvestris from Russia. Our purpose was to provide basic information that can help wood processing mills set their VOCs emission limits and control the exhaust gas within such limits. During conventional drying of the plantation Pinus sylvestris, a total of 22 chemical compounds were detected in the exhaust gas: 9 aldehydes including formaldehyde, 8 terpenes including a-pinene, and 3 additional compounds including alkane, and propylbenzene. The VOCs released during both conventional drying and high-temperature drying were the same. However, large amounts of benzene were detected during the high-temperature drying process. During conventional drying of the Russian Pinus sylvestris material, a total of 17 chemical compounds were detected: 7 aldehydes including formaldehyde, 6 terpenes including a-pinene, and 2 additional compounds. The VOCs released during conventional drying and high-temperature drying were the same. However, large amounts of camphene were detected during high-temperature drying. For plantation Pinus sylvestris, the release of VOCs primarily took place at the later stage of conventional drying, and at the earlier stage of high-temperature drying. For Russian Pinus sylvestris, the amount and the release rate of VOCs during conventional drying were extremely low, and the VOCs during hightemperature drying were primarily released at the later stage. The total amount of VOCs released during drying was much higher from the plantation Pinus sy/vestris than from Russian Pinus sylvestris material.
\end{abstract}

Keywords: Pinus sylvestris, Volatile organic compounds (VOCs), Conventional drying, High-temperature drying

\section{Introduction}

The texture of Pinus sylvestris is straight, the pattern is clear, the structure is moderately uniform, the material is light and the density is small. It has a rosin smell, is resistant to water and moisture, is resistant to fungal corrosion, and has high durability. It is the main production material of wood processing enterprises at present, most of which are used as structural materials, and structural

\footnotetext{
*Correspondence: yjf_112@163.com; duohuaqiong@163.com; wangximing@imau.edu.cn

${ }^{\dagger}$ Yulin Shen, Xiaotao Zhang and Qin He contributed equally to this paper ${ }^{1}$ College of Material Science and Art Design, Inner Mongolia Agricultural University, Hohhot 010018, China

Full list of author information is available at the end of the article
}

materials must be dried before use. During wood drying, large amounts of VOCs are usually released and typically include terpenes, aldehydes, and alcohols [1, 2], so the discovery and solution of environmental pollution caused by wood-drying process has received extensive attention in recent years.

The US EPA defines VOCs as carbon compounds that participates in photochemical reaction, except $\mathrm{CO}_{2}, \mathrm{CO}$, $\mathrm{H}_{2} \mathrm{CO}_{3}$, metal carbides, metal carbonates and ammonium carbonate. VOCs could interfere with photosynthesis of plants, and some may react with each other under certain conditions resulting in secondary pollution, which may negatively affect human health and the environment during processing and utilization [3, 4]. Because
Springer Open (c) The Author(s) 2020. This article is licensed under a Creative Commons Attribution 4.0 International License, which permits use, sharing, adaptation, distribution and reproduction in any medium or format, as long as you give appropriate credit to the original author(s) and the source, provide a link to the Creative Commons licence, and indicate if changes were made. The images or other third party material in this article are included in the article's Creative Commons licence, unless indicated otherwise in a credit line to the material. If material is not included in the article's Creative Commons licence and your intended use is not permitted by statutory regulation or exceeds the permitted use, you will need to obtain permission directly from the copyright holder. To view a copy of this licence, visit http://creativeco mmons.org/licenses/by/4.0/. 
of these factors, the "environmentally friendly" and "human health and safety" of the wood-drying industry have created new challenges, especially the promotion of high-temperature and efficient drying methods and the discharge treatment of VOCs $[5,6]$. In recent years, studies of the release of VOCs have been carried out and were mainly focused on the effects of drying temperature, wood moisture content (MC), and wood properties on the amount and the constituents of the released VOCs. It was found that the concentration of VOCs in drying medium increased with drying temperature, and that drying temperature had a particularly large influence on the release of terpenes $[1,7,8]$, because under the high temperatures, to promote the degradation of the cell wall, but also to accelerate the evaporation of low-molecularweight components (e.g., Volatile oil, etc.) [9]. It was also found that the lower the final MC of wood, the higher the total amount of VOCs released $[1,10]$. The release rate of VOCs quickly increased when drying continued under $12 \% \mathrm{MC}$ [1]. The amount of released aldehyde, methanol, methanoic acid, and acetic acid can be considerably reduced by lowering drying temperature and ending drying at higher final MC $[11,12]$. Some studies found that the amount and constituents of VOCs released during drying differed between softwoods and hardwoods, softwoods released more VOCs than hardwoods [12, 13], and that heartwood released more VOCs than sapwood [14-16]. The harvesting season also had some influence on the release of VOCs $[17,18]$.

Since the end of 2018, China has promulgated and implemented the national standard of "General principles for the assessment of green factories" (GB/T361322018 ), indicating the government is paying more and more attention to pollutant emissions from industrial production. It is of great significance to report the VOCs release. Different kinds of adsorbent materials can be studied according to the components and selected to add in the designated drying stage, so as to realize the intelligent VOC capture technology in the drying process.

\section{Materials and methods Materials}

Plantation-grown Pinus sylvestris trees 13-15 years old were harvested in winter at Weichang Town plantation farm, Manchu and Mongol Autonomous County, Hebei Province, China. The diameter at breast height (DBH) was $20-30 \mathrm{~cm}$. The logs were sawn at a local sawmill. The Russian Pinus sylvestris logs were purchased at a log and wood market, Hohhot. It was known that the logs were harvested from natural Pinus sylvestris forests in the Far East of Russia in winter and the trees were $30-40$ years old at the harvest time. The logs were $4 \mathrm{~m}$ long, the average diameter at the large end was $40 \mathrm{~cm}$, and were sawn at a local sawmill. From the sawn materials of both origins, study boards were selected and immediately wrapped after sawing, then transported and stored in a freezer at Inner Mongolia Agricultural University, Hohhot. A total of 24 specimens of $100 \times 30 \times 400 \mathrm{~mm}(R \times T \times L)$ were prepared from the study boards and their average initial MC and densities are given in Table 1. In Table 1, "At 12\% $M C$ " and "Oven-dry" represent air-dry density and ovendry density, respectively.

\section{Drying}

A drier (GDJSX-120A, Shanghai Yuejin Company, China) that facilitates alternating high or low drying temperatures and varying humidities was used. The drying chamber has 6 shelves and 4 specimens were put on each shelf. The air flew primarily parallel to the shelves, not across the shelves, and the fan speed was $1.5 \mathrm{~m} / \mathrm{s}$. For conventional drying, the dry temperature was set at $90{ }^{\circ} \mathrm{C}$. For high-temperature drying, the dry temperature was set at $120^{\circ} \mathrm{C}$. It is worth noting that the dryer's inside temperature is constant over time.

In order to ensure the accuracy of the experiment, nitrogen was used to clean the drying kiln for $10 \mathrm{~min}$ before drying and then discharged through the collection device.

\section{Collection and analysis of VOCs}

A universal collection equipment (Laoying 2050, Qingdao Laoying Environmental Technology Company, China) was used to collect both air samples and the total suspended particles (TSP). The collection speed was $0.5 \mathrm{~L} / \mathrm{min}$. The exhaust gas from the drying chamber entered into the collection equipment through two different adsorption tubes. Formaldehyde was collected via 3-methyl-2-benzothiazolinone hydrazonehydrochloride hydrate $(\mathrm{MBTH})$ located in one tube. Other VOCs were collected simultaneously via the other one, as shown in Fig. 1. The types of VOCs were collected every $4 \mathrm{~h}$ for conventional drying, and every $3 \mathrm{~h}$ for high-temperature drying (because the drying time at high temperature is shortened and the moisture content changes quickly, the collection time interval is shortened). Each collection lasted $20 \mathrm{~min}$. The $\mathrm{MC}$ specimens were taken out quickly from the dryer at the end of each VOCs gas collection period, weighed, then returned back to the

Table 1 The Pinus sylvestris specimens

\begin{tabular}{llll}
\hline Origin & $\begin{array}{l}\text { Average initial MC } \\
\text { (\%) }\end{array}$ & Density $\left(\mathbf{k g} / \mathbf{m}^{\mathbf{3}}\right)$ & \\
\cline { 3 - 4 } & & At 12\% MC & Oven-dry \\
\hline China & 85.32 & 440 & 390 \\
Russia & 70.74 & 480 & 410 \\
\hline
\end{tabular}




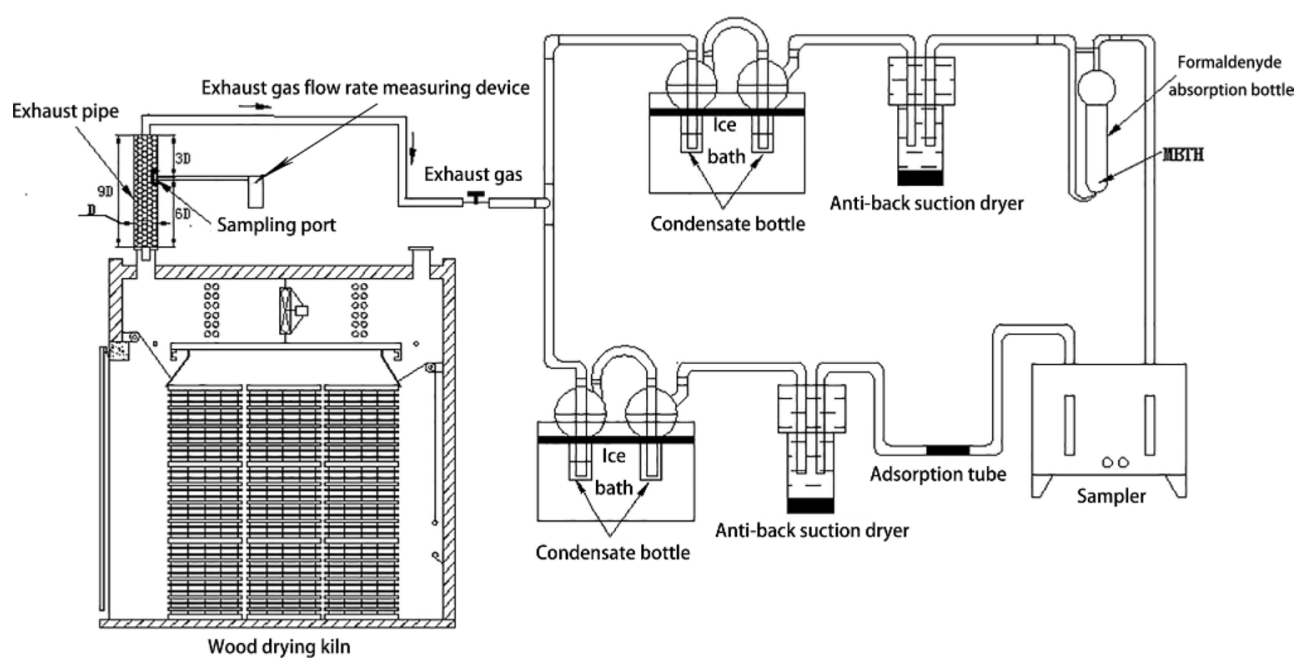

Fig. 1 VOCs collection device during drying

dryer. The initial MC, MC at different drying periods, and the final average $\mathrm{MC}$ were determined.

Air samples were analyzed with a gas chromatographymass spectrometry (GC-MS) system (Clarus 580, PERKINELMER). Formaldehyde analysis by phenol reagent spectrophotometry with the GB/T18204.2-2014 Gas chromatography-mass spectrometry analysis is as follows.

Gas chromatography conditions: chromatographic column, PERKINELMER Elite-624 Capillary column $(30 \mathrm{~m} \times 0.25 \mathrm{~mm} \times 1.4 \mu \mathrm{m})$; split ratio, $50: 1$; injection port, $200{ }^{\circ} \mathrm{C}$; carrier gas, ultra-pure helium; oven temperature program, $40{ }^{\circ} \mathrm{C}$ for $5 \mathrm{~min}$, to $100^{\circ} \mathrm{C}$ at $8{ }^{\circ} \mathrm{C} / \mathrm{min}$ for $5 \mathrm{~min}$, to $200^{\circ} \mathrm{C}$ at $6^{\circ} \mathrm{C} / \mathrm{min}$ for $10 \mathrm{~min}$; flowrate, $1 \mathrm{~mL} / \mathrm{min}$.

MS conditions: ion source, electron ionization; ionization energy, $70 \mathrm{eV}$; auxiliary heating zone, $280{ }^{\circ} \mathrm{C}$; ion source, $230{ }^{\circ} \mathrm{C}$; quadrupole, $150{ }^{\circ} \mathrm{C}$; data acquisition mode, full scan; mass scanning range, $\mathrm{m} / \mathrm{z}$ 50-550; solvent delay: 3 min.

The GC-MS spectra were analyzed via a computerbased automatic search, the automated and manual analyses of a mass spectral library (NIST), and a literature search to identify each component. Finally, the relative contents of each constituent were calculated using the peak area normalization method [19].

\section{Calculation}

\section{Concentration of VOCs ( $\mathrm{mg} / \mathrm{m}^{3}$ of exhaust gas)}

$$
H_{i}=\frac{C_{i}}{2 \times S t}, \quad i=1,2,3 \ldots,
$$

where $H_{i}$ is the VOCs concentration in exhaust gas at each stage $\left(\mathrm{mg} / \mathrm{m}^{3}\right.$ of exhaust gas). $C_{i}$ is the VOCs content measured at each stage $(\mathrm{mg}) . S$ is the collection speed, $0.5 \mathrm{~L} / \mathrm{min}=0.5 \times 10^{-3} \mathrm{~m}^{3} / \mathrm{min} . t$ is the collection time (min).

Total ( $\mathrm{mg} / \mathrm{m}^{3}$ of wood)

$$
C_{T}=\frac{\sum C_{i}}{V_{w}}, \quad i=1,2,3 \ldots,
$$

where $C_{T}$ is the VOCs content $/ \mathrm{m}^{3}$ of wood $\left(\mathrm{mg} / \mathrm{m}^{3}\right.$ of wood) and $V_{w}$ is the total volume of $\operatorname{wood}\left(\mathrm{m}^{3}\right)$.

\section{Release rate of VOCs}

$$
R=\frac{C_{i}}{V_{w} t_{d}}, \quad i=1,2,3 \ldots,
$$

where $R$ is the release rate of VOCs $\left(\mathrm{mg} / \mathrm{m}^{3} \mathrm{~h}\right)$ and $t_{d}$, the collection interval (h).

\section{Results and discussion \\ VOCs released from plantation Pinus sylvestris Constituents and amount of VOCs}

The constituents and amount of VOCs released during each drying period, and the average MC determined at the end of each drying period, are given in Table 2 for conventional drying, and in Table 3 for high-temperature drying.

Table 2 shows that during conventional drying of plantation Pinus sylvestris, the average MC dropped from the initial $55.91 \%$ to $8.78 \%$, a total of 20 compounds were detected: 9 different aldehydes including formaldehyde, 
Table 2 Constituents and amount of VOCs released during each period of conventional drying (plantation Pinus sylvestris)

\begin{tabular}{|c|c|c|c|c|c|c|c|}
\hline \multirow[t]{2}{*}{ VOCs and MC } & \multicolumn{6}{|c|}{ Concentration of VOCs ( $\mathrm{mg} / \mathrm{m}^{3}$ of exhaust gas) } & \multirow{2}{*}{$\begin{array}{l}\text { Total (mg/ } \\
\mathrm{m}^{3} \text { of wood) }\end{array}$} \\
\hline & $0-4 \mathrm{~h}$ & $4-8 \mathrm{~h}$ & $8-12 h$ & $12-20 \mathrm{~h}$ & $20-24 \mathrm{~h}$ & $24-28 \mathrm{~h}$ & \\
\hline Formaldehyde & 0.74 & 0.54 & 1.00 & 0.37 & 0.72 & 0.84 & 2.92 \\
\hline Acetaldehyde & 0.01 & 0.04 & 0.01 & 2.88 & - & 0.01 & 2.04 \\
\hline n-Propanal & 1.14 & 21.03 & 7.85 & 6.49 & 0.32 & 0.02 & 25.59 \\
\hline n-Butyraldehyde & 0.07 & 1.78 & 0.63 & 3.79 & 0.01 & 0.01 & 4.37 \\
\hline n-Hexanal & 2.15 & 6.65 & 2.48 & 26.47 & 0.92 & 0.02 & 26.86 \\
\hline Acraldehyde & 0.25 & 1.54 & 0.42 & 3.72 & 0.02 & $\Delta$ & 4.14 \\
\hline Iso-valeraldehyde & 0.02 & 0.02 & 0.01 & 0.07 & 0.01 & $\Delta$ & 0.09 \\
\hline n-Valeraldehyde & 1.22 & 6.48 & 3.22 & 28.74 & 0.14 & 0.02 & 27.65 \\
\hline Benzaldehyde & 0.39 & 0.09 & 0.11 & 0.05 & 0.92 & $\mathbf{\Delta}$ & 1.09 \\
\hline a-Pinene & 14.47 & 16.06 & 22.86 & 18.75 & 72.20 & $\Delta$ & 100.24 \\
\hline Camphene & 0.37 & 0.75 & 0.75 & 0.57 & 2.53 & $\Delta$ & 3.46 \\
\hline Myrcene & 0.46 & 0.07 & 0.09 & 0.03 & 1.08 & - & 1.20 \\
\hline$\beta$-Pinene & 2.09 & 0.08 & 0.10 & 0.05 & 1.26 & $\Delta$ & 2.48 \\
\hline a-Phellandrene & 2.29 & 0.70 & 0.89 & 0.61 & 5.42 & $\Delta$ & 6.88 \\
\hline Limonene & 2.41 & 0.55 & 0.09 & 0.33 & 5.86 & - & 6.41 \\
\hline r-Oilene & 0.07 & 0.02 & 0.02 & 0.01 & 0.15 & - & 0.18 \\
\hline 1-Heptene & 0.33 & 1.69 & 0.46 & 3.33 & 0.02 & $\Delta$ & 4.05 \\
\hline n-Heptane & 0.04 & 0.03 & 0.40 & 2.30 & 0.02 & $\Delta$ & 1.94 \\
\hline 2,4-Dimethyl hexane & 0.32 & 1.79 & 0.86 & 7.86 & 0.03 & $\Delta$ & 7.55 \\
\hline Propylbenzene & 0.09 & 0.05 & 0.07 & 0.04 & 0.45 & - & 0.49 \\
\hline Average MC \% & 55.91 & 43.06 & 24.70 & 13.66 & 10.79 & 8.78 & \\
\hline
\end{tabular}

"-" indicates VOCs undetectable." $\mathbf{\Delta}$ "indicates VOCs were detected, but less than $0.005 \mathrm{mg}$. This also applies to the following tables

8 different terpenes including $\alpha$-pinene, and 3 additional compounds including alkane and propylbenzene. Most of the VOCs were terpenes $\left(124.90 \mathrm{mg} / \mathrm{m}^{3}\right.$ of wood), such as $80 \%$ was $\alpha$-pinene $\left(100.24 \mathrm{mg} / \mathrm{m}^{3}\right.$ of wood). From Table 2, it also can be seen that large amount of $\alpha$-pinene was released at the early stages of drying and reached the highest VOC concentration of $72.20 \mathrm{mg} / \mathrm{m}^{3}$ around $10 \%$ MC. Similarly, the amount of other released terpenes also reached the highest around $10 \% \mathrm{MC}$, as indicated by the VOCs concentration values. The next large release of VOCs was aldehydes $\left(94.13 \mathrm{mg} / \mathrm{m}^{3}\right.$ of wood), which mostly included $n$-propanal $(25.59 \mathrm{mg}), n$-hexanal (26.864 $\mathrm{mg}$ ) and $n$-valeraldehyde $(27.65 \mathrm{mg})$. The concentration of $n$-propanal, formaldehyde and all other aldehyde was relatively highest around 40\% MC, 30\% MC, and $15 \% \mathrm{MC}$, respectively. The total amount of released alkane and propylbenzene was $9.98 \mathrm{mg}$, and the concentration of each of these VOCs also reached the highest values around 15\% MC. In conclusion, all of the above results showed that the release of VOCs from the plantation Pinus sylvestris during conventional drying primarily occurred at the later drying stage.

Table 3 shows that during high-temperature drying, the average MC dropped from the initial $62.58 \%$ to $5.18 \%$, and the released VOCs showed the same trends as during conventional drying, whereas one more VOCs, benzene, was detected in a large amount $\left(84.99 \mathrm{mg} / \mathrm{m}^{3}\right.$ of wood). The concentration of the released VOCs was between $20 \mathrm{mg} / \mathrm{m}^{3}$ and $25 \mathrm{mg} / \mathrm{m}^{3}$, in similar range as during the conventional drying process. The total amount of released terpenes was $899.35 / \mathrm{m}^{3}$ of wood, not only again higher than any other VOCs, but also was considerably higher by more than 6 times compared to conventional drying. The amount of released $\alpha$-pinene, $\beta$-pinene, myrcene, camphene, and limonene also increased considerably compared to conventional drying. The concentration of $\alpha$-pinene and camphene reached the highest around $10 \% \mathrm{MC}$, yet the concentration of other terpene VOCs reached maximum around 50\% MC. The total released aldehyde per $\mathrm{m}^{3}$ of wood was $417.43 \mathrm{mg}, 3.4$ times more than that during conventional drying, and the main constituents $n$-propanal, $n$-hexanal and $n$-valeraldehyde were all considerably higher; $n$-hexanal in fact increased by 8.9 times, reaching $267.10 \mathrm{mg}$. The amount of released benzaldehyde also increased. The concentration of $n$-propanal was high at both the early and later drying stages, but the other aldehydes were all released at the early drying stage. The amount of released alkane and 
Table 3 Constituents and amount of VOCs released during each period of high-temperature drying (plantation $P$. sylvestris)

\begin{tabular}{|c|c|c|c|c|c|c|c|}
\hline \multirow[t]{2}{*}{ VOCs and MC } & \multicolumn{6}{|c|}{ Concentration of VOCs ( $\mathrm{mg} / \mathrm{m}^{3}$ of exhaust gas) } & \multirow{2}{*}{$\begin{array}{l}\text { Total (mg/ } \\
\mathrm{m}^{3} \text { of wood }\end{array}$} \\
\hline & $0-3 \mathrm{~h}$ & $3-6 h$ & $6-9 h$ & $9-12 \mathrm{~h}$ & $12-15 \mathrm{~h}$ & $15-21 \mathrm{~h}$ & \\
\hline Formaldehyde & 0.14 & 0.70 & 0.44 & 0.26 & 0.12 & 0.69 & 1.63 \\
\hline Acetaldehyde & 1.77 & 1.52 & 1.11 & 0.53 & 0.34 & 0.16 & 3.77 \\
\hline n-Propanal & 17.73 & 18.05 & 15.75 & 6.72 & 23.33 & 16.35 & 68.00 \\
\hline n-Butyraldehyde & 1.95 & 2.27 & 1.83 & 1.13 & 0.53 & 0.15 & 5.46 \\
\hline n-Hexanal & 78.53 & 208.36 & 71.97 & 21.69 & 2.86 & 1.21 & 267.10 \\
\hline Acraldehyde & 0.35 & 0.45 & 0.38 & 0.21 & 0.73 & 1.02 & 2.18 \\
\hline Iso-valeraldehyde & 0.34 & 0.39 & 0.32 & 0.20 & 0.47 & 0.55 & 1.57 \\
\hline n-Valeraldehyde & 22.87 & 25.35 & 11.35 & 5.90 & 1.61 & 1.02 & 47.30 \\
\hline Benzaldehyde & 0.39 & 9.75 & 3.56 & 11.09 & 3.43 & 1.18 & 20.42 \\
\hline a-Pinene & 84.93 & 189.11 & 151.31 & 104.06 & 250.32 & 118.58 & 623.83 \\
\hline Camphene & 1.64 & 7.86 & 5.44 & 3.07 & 18.90 & 6.36 & 30.04 \\
\hline Myrcene & 0.31 & 60.40 & 39.15 & 19.46 & 4.69 & 1.29 & 87.01 \\
\hline$\beta$-Pinene & 0.37 & 72.69 & 46.01 & 22.62 & 5.53 & 6.42 & 106.68 \\
\hline a-Phellandrene & 1.18 & 2.67 & 1.24 & 0.63 & 0.42 & 0.13 & 4.35 \\
\hline Limonene & 0.26 & 16.60 & 14.11 & 9.99 & 3.69 & 8.10 & 36.63 \\
\hline r-Oilene & 0.03 & 2.54 & 1.65 & 1.03 & 0.47 & 0.18 & 4.10 \\
\hline 1-Heptene & 3.23 & 1.97 & 1.51 & 1.33 & 0.66 & 0.96 & 6.71 \\
\hline n-Heptane & 0.56 & 0.68 & 0.55 & 0.34 & 0.67 & 0.83 & 2.52 \\
\hline 2,4-Dimethyl hexane & 6.27 & 7.68 & 3.55 & 1.85 & 0.45 & 0.27 & 13.94 \\
\hline Benzene & 12.12 & 20.04 & 27.37 & 18.88 & 17.71 & 26.26 & 84.99 \\
\hline Propylbenzene & 0.25 & 2.28 & 1.301 & 0.83 & 2.54 & 0.67 & 5.46 \\
\hline Average MC \% & 62.58 & 49.36 & 33.52 & 20.98 & 11.06 & 5.18 & \\
\hline
\end{tabular}

propylbenzene all increased compared to conventional drying, with the total amount per $\mathrm{m}^{3}$ of wood reaching $21.92 \mathrm{mg}$, and the concentration of each of these VOCs also reached the highest values around $49.36 \% \mathrm{MC}$.

During both conventional and high-temperature drying, the primary VOCs released were terpene and aldehyde. In addition, large amount of benzene was released during high-temperature drying. Terpene compounds were mostly $\alpha$-pinene and $\beta$-pinene. Aldehyde compounds were substantial $n$-propanal, $n$-hexanal and $n$-valeraldehyde. The total amount of VOCs released was $1423.69 \mathrm{mg}$ during high-temperature drying, 6 times higher than that $(229 \mathrm{mg})$ during conventional drying.

\section{Release rate of VOCs}

Figure 2 shows respective release rate of formaldehyde, $n$-propanal, $n$-hexanal, $n$-valeraldehyde, and other aldehydes during conventional and high-temperature drying. The release rate is represented by the weight of the VOCs released from $1 \mathrm{~m}^{3}$ of wood per hour; it can be seen Eq. (3).

During conventional drying (Fig. 2a), the release rate of formaldehyde remained relatively stable and low, and reached highest merely at $0.25 \mathrm{mg} /\left(\mathrm{m}^{3} \mathrm{~h}\right)$. The release rate of $n$-propanal increased at the early stage of drying (e.g., the first $8 \mathrm{~h}$ ) reaching the highest value of $5.25 \mathrm{mg} /$ $\left(\mathrm{m}^{3} \mathrm{~h}\right)$, then decreased during the rest of the drying. The release rate of the other VOCs all increased during the first $6 \mathrm{~h}$, then decreased slightly at the mid-stage of drying, then increased considerably and reached highest around $15 \%$ MC. The release rate of $n$-hexanal, $n$-valeraldehyde and other aldehydes reached highest of $6.61 \mathrm{mg} /$ $\left(\mathrm{m}^{3} \mathrm{~h}\right), 7.18 \mathrm{mg} /\left(\mathrm{m}^{3} \mathrm{~h}\right)$ and $2.62 \mathrm{mg} /\left(\mathrm{m}^{3} \mathrm{~h}\right)$, respectively, and gradually decreased until close to the end of drying.

During high-temperature drying (Fig. 2b), the variations and the ranges of release rate for formaldehyde were relatively similar to those during conventional drying. The release rate of other aldehydes all reached maximum during the first $6 \mathrm{~h}$ of drying, then started to decrease as drying continued. The highest release rate of $n$-propanal, $n$-hexanal, $n$-valeraldehyde and the rest of the aldehydes were $6.01 \mathrm{mg} /\left(\mathrm{m}^{3} \mathrm{~h}\right), 69.45 \mathrm{mg} /\left(\mathrm{m}^{3} \mathrm{~h}\right), 8.45 \mathrm{mg} /\left(\mathrm{m}^{3} \mathrm{~h}\right)$ and $4.79 \mathrm{mg} /\left(\mathrm{m}^{3} \mathrm{~h}\right)$, respectively. It is clear that high-temperature drying resulted in considerable increase in the release rate of aldehydes, in particular $n$-hexanal. Steam and fog that contain hexanal could irritate eyes, mucosa and upper respiratory tract, and cause coughing, headache, retrosternal pain and breathing difficulties. 

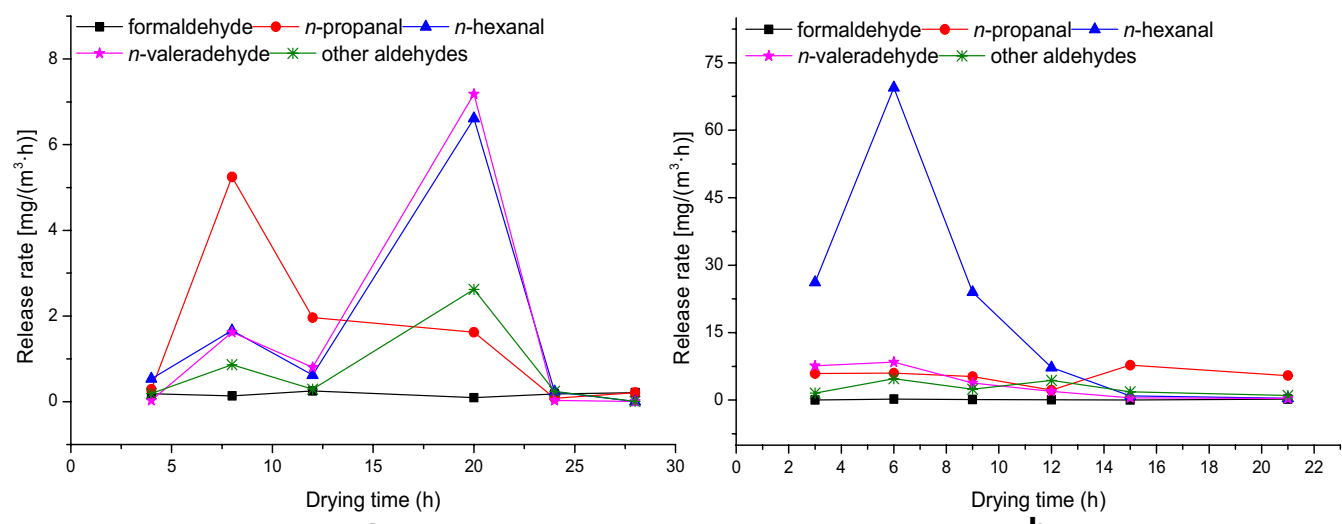

a

b

Fig. 2 Variations of release rate of aldehydes during a conventional drying, and $\mathbf{b}$ high-temperature drying

Figure 3 shows respective release rate of $\alpha$-pinene, camphene, myrcene, $\beta$-pinene, limonene and other terpenes during conventional drying (Fig. 3a) and during hightemperature drying (Fig. 3b). During conventional drying (Fig. 3a), the release rate of terpenes increased gradually from the beginning, then raised considerably at the later drying stage until reaching the maximum around the 24th $\mathrm{h}$, then decreased and dropped almost to zero at the end of drying. The highest release rate of $\alpha$-pinene, camphene, myrcene, $\beta$-pinene, limonene and other terpenes were $18.04 \mathrm{mg} /\left(\mathrm{m}^{3} \mathrm{~h}\right), 0.63 \mathrm{mg} /\left(\mathrm{m}^{3} \mathrm{~h}\right), 0.027 \mathrm{mg} /$ $\left(\mathrm{m}^{3} \mathrm{~h}\right), 0.315 \mathrm{mg} /\left(\mathrm{m}^{3} \mathrm{~h}\right), 1.463 \mathrm{mg} /\left(\mathrm{m}^{3} \mathrm{~h}\right)$, and $1.396 \mathrm{mg} /$ $\left(\mathrm{m}^{3} \mathrm{~h}\right)$, respectively. During the entire drying process, the release rate of $\alpha$-pinene was much higher than any other terpenes.

In the process of high-temperature drying (Fig. 3b), the release rate of $\alpha$-pinene gradually increased during the first $6 \mathrm{~h}$, started to decrease at the mid-stage of drying, then increased considerably at the later stage, finally decreased again near the end of drying to almost the same level as the mid-stage of drying. It reached the highest of $63.03 \mathrm{mg} /\left(\mathrm{m}^{3} \mathrm{~h}\right)$ during the early stage, and highest of $83.44 \mathrm{mg} /\left(\mathrm{m}^{3} \mathrm{~h}\right)$ during the later stage of drying. The release rate of camphene remained stable at 5-7 mg/ $\left(\mathrm{m}^{3} \mathrm{~h}\right)$ during the mid-stage of drying, and reached highest at the later stage of drying. The release rate of other terpenes gradually increased at the early stage of drying and reached highest around the 6 th $h$, then decreased during the remaining hours of drying. The release rate of terpenes during high-temperature drying were higher than those during conventional drying, especially for $\beta$-pinene, which showed a considerably higher release rate.

Figure 4 shows respective release rate of alkane and benzene during conventional drying (Fig. 4a) and during high-temperature drying (Fig. 4b). During conventional drying (Fig. 4a), the release rate of the VOCs increased gradually and reached the highest at the later stage.
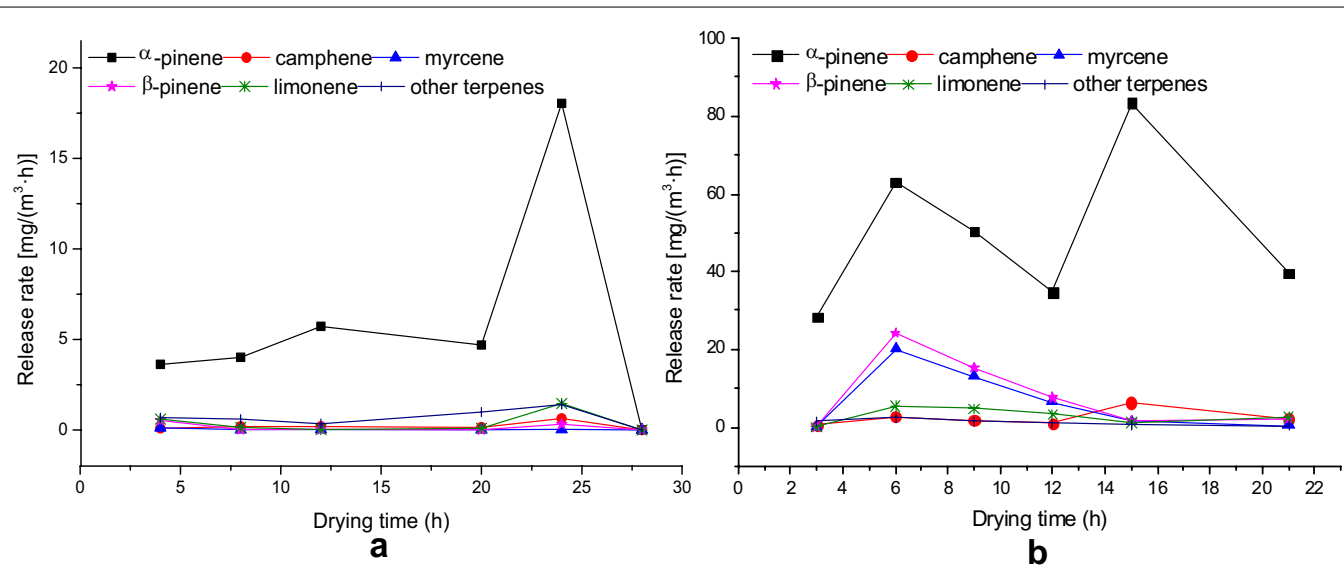

Fig. 3 Variations of release rate of terpenes during a conventional drying, and $\mathbf{b}$ high-temperature drying 
During high-temperature drying (Fig. 4b), the release rate of benzene was far greater than other VOCs, it gradually increased during the early stage of drying, reached the highest of $9.12 \mathrm{mg} /\left(\mathrm{m}^{3} \mathrm{~h}\right)$ around the 9th hour, then decreased, but slightly increased towards the end of drying. The release rate of other VOCs all reached highest at the early-to-mid stages of drying.

Figure 5 shows variations of release rate of the total amount of VOCs (TVOCs) during conventional and high-temperature drying. The release rate of TVOCs during conventional drying showed an opposite variation pattern compared to high-temperature drying (Fig. 5). During conventional drying, TVOCs increased slightly at the early stage, followed by a decrease, then increased considerably at the mid- and later-stages of drying, then quickly decreased towards the end of drying. During high-temperature drying, the release rate of TVOCs increased quickly at the early stage, followed by a fast decrease, then had a small increase at the later stage of drying. It is clear that the VOCs were mainly released at the mid- and later-stages during conventional drying, but mainly at the early stage during high-temperature drying.

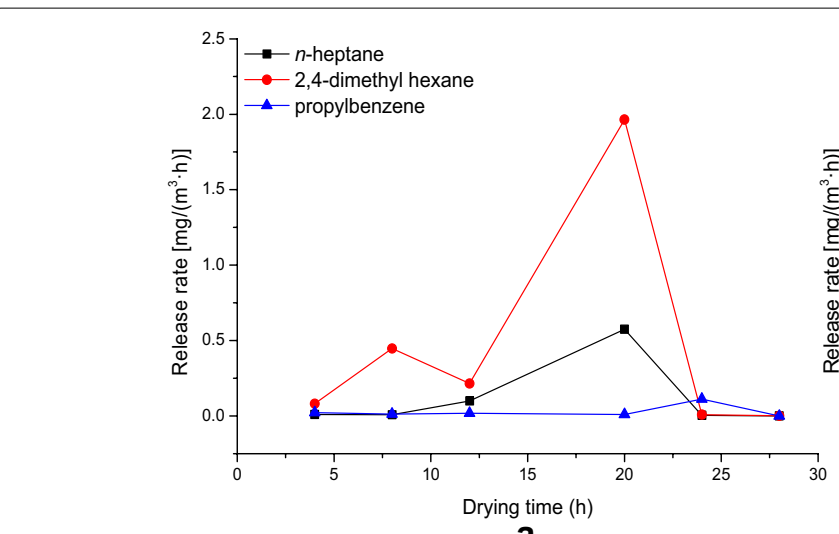

a

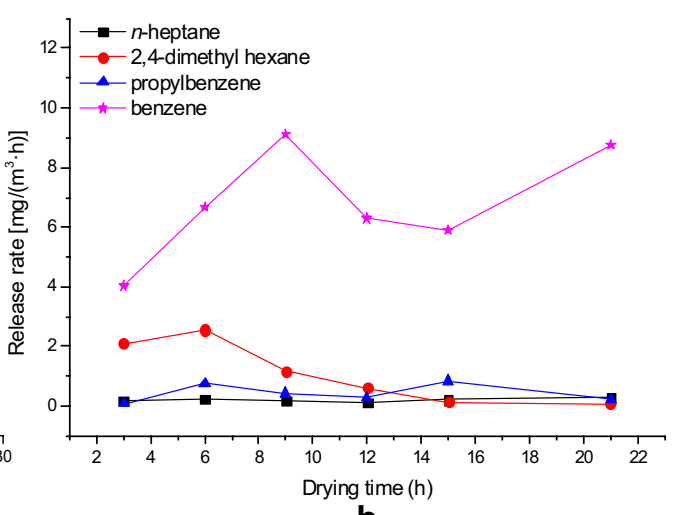

b

Fig. 4 Variations of release rate of alkane and benzene during a conventional drying, and $\mathbf{b}$ high-temperature drying

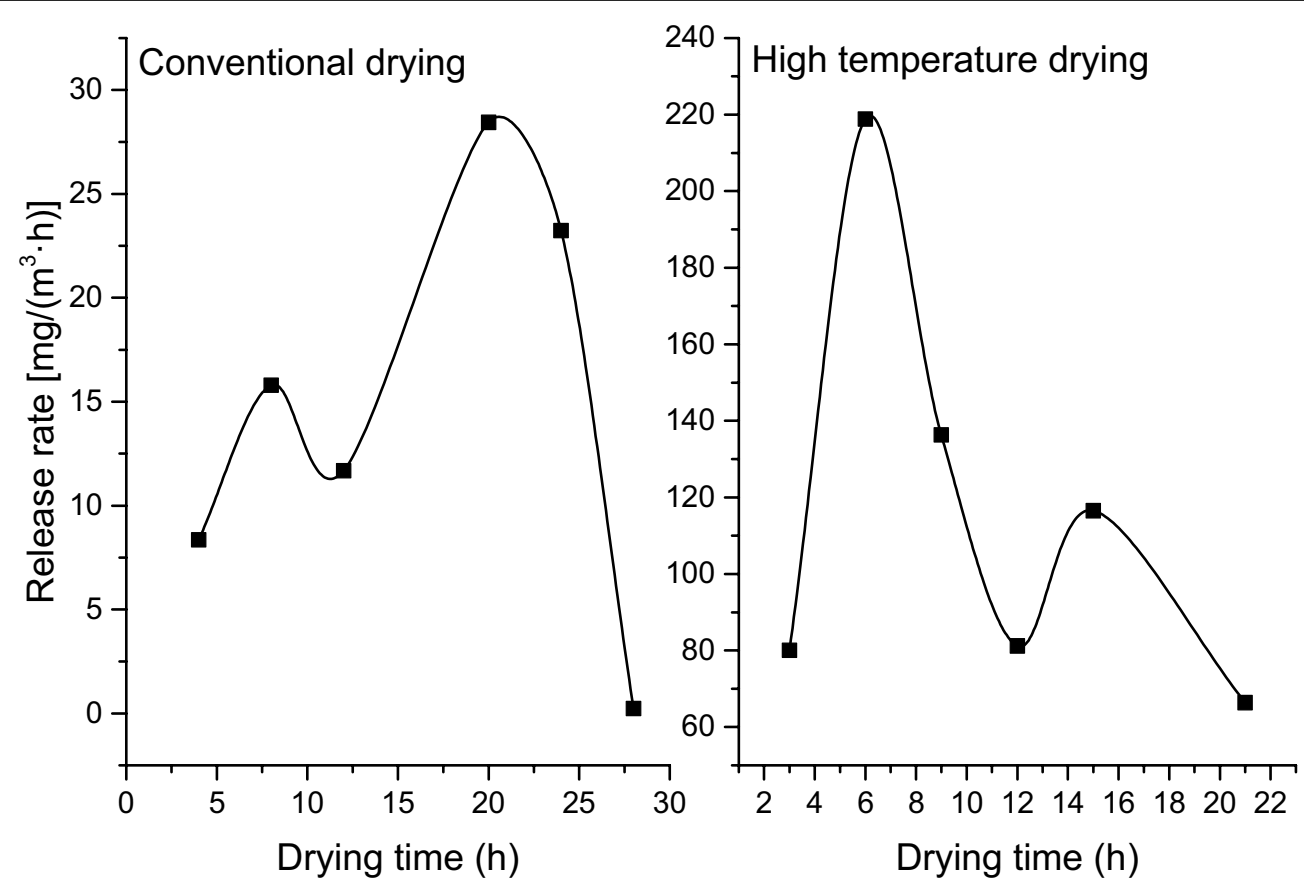

Fig. 5 Variations of release rate of TVOCs during conventional and high-temperature drying 
The degree of thermal degradation of the chemical composition of wood is directly related to the drying temperature [20]. There is a minimal degradation of cellulose above $200{ }^{\circ} \mathrm{C}[21,22]$; hemicellulose can basically degrade above $120^{\circ} \mathrm{C}$ [23]; extracts are easily degraded and volatile, such as rosin, grease, etc. [24]. Therefore, given the relatively low drying temperature and drying speed during conventional drying, the chemical composition and degradation of rosolic acid, extractives, cellulose, etc., were relatively slow, resulting in a lower release of VOCs. High-temperature drying, however, resulted in fast and near-complete chemical decomposition and degradation of rosolic acid, extractives, cellulose, etc., and subsequent release of large amounts of VOCs. In a word, the release rate of TVOCs was greater at every stage of high-temperature drying compared to conventional drying.

\section{VOCs released of Russian Pinus sylvestris Constituents and amount of VOCs}

The constituents and amount of VOCs released during each drying period, and the average $\mathrm{MC}$ determined at the end of each drying period, are listed in Table 4 for conventional drying, and in Table 5 for high-temperature drying.

Table 4 shows that during conventional drying of Russian P. sylvestris, the average MC decreased from the initial $55.86 \%$ to $10.2 \%$, a total of 15 compounds were detected: 7 different aldehydes including formaldehyde, 6 different terpenes including $\alpha$-pinene, and 2 additional different compounds. Most of the VOCs were terpene $\left(102.93 \mathrm{mg} / \mathrm{m}^{3}\right.$ of wood), $88.19 \%$ of which was $\alpha$-pinene $\left(90.50 \mathrm{mg} / \mathrm{m}^{3}\right.$ of wood). As shown in Table 4 , large amount of $\alpha$-pinene was released at the early stage of drying, reached highest around $40 \% \mathrm{MC}$, with a VOCs concentration of $42.90 \mathrm{mg} / \mathrm{m}^{3}$. Similarly, the highest VOCs concentration of $\beta$-pinene was observed around $40 \% \mathrm{MC}$. Aldehydes ranked as the second group in terms of the amount of VOCs released, the total was $18.32 \mathrm{mg} /$ $\mathrm{m}^{3}$ of wood and contained $3.47 \mathrm{mg}, 4.49 \mathrm{mg}, 3.24 \mathrm{mg} / \mathrm{m}^{3}$ of wood, for $n$-propanal, $n$-hexanal and benzaldehyde, respectively. The concentration of $n$-propanal, $n$-hexanal, $n$-valeraldehyde and acraldehyde reached maximum around $40 \% \mathrm{MC}$, whereas the concentration of formaldehyde and iso-valeraldehyde reached highest around $30 \% \mathrm{MC}$. The combined amount of released alkane was $2.371 \mathrm{mg} / \mathrm{m}^{3}$ of wood, and their concentration reached highest around $40 \%$ MC. The above results clearly showed that for the Russian P. sylvestris, the VOCs were released mainly at the early stage of conventional drying as indicated by both the amount released and the VOCs concentration.

Table 5 shows that during high-temperature drying, the average MC dropped from the initial $51.45 \%$ to $9.64 \%$, the same 16 VOCs were released as during conventional drying, and a large amount camphene was detected. The amount of released terpene was higher than any other VOCs, the total was $229.57 \mathrm{mg} / \mathrm{m}^{3}$ of wood, and was 1.2 times higher than that during conventional drying. The amount of $\alpha$-pinene, $\beta$-pinene, limonene and 1-heptene were all considerably higher. The concentration

Table 4 Constituents and amount of VOCs released during each period of conventional drying (Russian Pinus sylvestris)

\begin{tabular}{|c|c|c|c|c|c|c|}
\hline \multirow[t]{2}{*}{ VOCs and MC } & \multicolumn{5}{|c|}{ Concentration of VOCs ( $\mathrm{mg} / \mathrm{m}^{3}$ of exhaust gas) } & \multirow{2}{*}{$\begin{array}{l}\text { Total (mg/ } \\
\mathrm{m}^{3} \text { of wood) }\end{array}$} \\
\hline & $0-4 \mathrm{~h}$ & $4-8 \mathrm{~h}$ & $8-12 h$ & $12-20 \mathrm{~h}$ & $20-24 \mathrm{~h}$ & \\
\hline Formaldehyde & 0.47 & 0.51 & 0.71 & 0.10 & 0.12 & 1.33 \\
\hline n-Propanal & 1.50 & 3.50 & - & - & - & 3.48 \\
\hline n-Hexanal & 0.34 & 3.70 & 1.79 & 0.34 & 0.31 & 4.49 \\
\hline Acraldehyde & 0.87 & 0.87 & 0.24 & 0.52 & 0.52 & 2.10 \\
\hline Iso-valeraldehyde & 0.44 & 0.48 & 0.12 & 0.30 & 0.22 & 1.09 \\
\hline n-Valeraldehyde & 0.32 & 2.44 & 0.40 & 0.26 & 0.32 & 2.59 \\
\hline Benzaldehyde & 0.08 & 1.31 & 1.77 & 0.90 & 0.61 & 3.24 \\
\hline a-Pinene & 4.05 & 42.90 & 26.66 & 40.50 & 16.22 & 90.50 \\
\hline Myrcene & 0.03 & 0.96 & 1.54 & 0.58 & 0.76 & 2.68 \\
\hline$\beta$-Pinene & 1.55 & 2.19 & 1.03 & 1.62 & 0.81 & 5.00 \\
\hline a-Phellandrene & 0.04 & 0.15 & - & 0.12 & - & 0.22 \\
\hline Limonene & - & 1.63 & 2.42 & 0.38 & 0.35 & 3.32 \\
\hline 1-Heptene & 0.50 & 0.54 & 0.13 & 0.34 & 0.28 & 1.24 \\
\hline n-Heptane & 0.67 & 0.76 & 0.19 & 0.44 & 0.39 & 1.70 \\
\hline 2,4-Dimethyl hexane & 0.08 & 0.69 & 0.11 & 0.06 & 0.04 & 0.67 \\
\hline Average MC \% & 55.86 & 42.28 & 31.98 & 16.44 & 10.2 & \\
\hline
\end{tabular}


Table 5 Constituents and amount of VOCs released during each period of high-temperature drying (Russian Pinus sylvestris)

\begin{tabular}{|c|c|c|c|c|c|c|}
\hline \multirow[t]{2}{*}{ VOCs and MC } & \multicolumn{5}{|c|}{ Concentration of VOCs ( $\mathrm{mg} / \mathrm{m}^{3}$ of exhaust gas) } & \multirow{2}{*}{$\begin{array}{l}\text { Total ( } \mathrm{mg} / \\
\mathrm{m}^{3} \text { of wood) }\end{array}$} \\
\hline & $0-3 \mathrm{~h}$ & $3-6 h$ & $6-9 h$ & $9-12 \mathrm{~h}$ & $12-15 \mathrm{~h}$ & \\
\hline Formaldehyde & 0.60 & 0.52 & 0.40 & 0.77 & 0.71 & 2.08 \\
\hline n-Propanal & 0.99 & 0.26 & 0.23 & 5.23 & 0.86 & 5.26 \\
\hline$n$-Hexanal & 1.88 & 8.61 & 3.11 & 49.88 & 3.67 & 46.64 \\
\hline Acraldehyde & 1.94 & 3.74 & 1.28 & 5.05 & 4.07 & 11.17 \\
\hline Iso-valeraldehyde & 1.26 & 1.81 & 0.45 & 10.02 & 2.23 & 10.96 \\
\hline n-Valeraldehyde & 2.00 & 4.92 & 0.60 & 51.89 & 1.89 & 42.57 \\
\hline Benzaldehyde & 6.98 & 7.37 & 3.14 & 4.59 & 2.79 & 17.28 \\
\hline a-Pinene & - & 32.69 & 12.67 & 11.66 & 108.58 & 115.00 \\
\hline Camphene & 0.33 & 1.38 & 1.42 & - & 2.59 & 3.97 \\
\hline Myrcene & 1.33 & 1.93 & 0.70 & 1.40 & 0.61 & 4.14 \\
\hline$\beta$-Pinene & 0.62 & 11.31 & 17.66 & 6.75 & 9.00 & 31.49 \\
\hline a-Phellandrene & 1.27 & 1.25 & 0.53 & - & 0.81 & 2.67 \\
\hline Limonene & 24.33 & 28.32 & 12.31 & 17.29 & 3.61 & 59.63 \\
\hline 1-Heptene & 1.37 & 2.70 & 0.80 & 10.52 & 2.57 & 12.47 \\
\hline n-Heptane & 1.77 & 2.73 & 0.74 & 3.33 & 3.25 & 8.211 \\
\hline 2,4-Dimethyl hexane & 0.70 & 1.25 & - & 14.50 & 0.56 & 11.81 \\
\hline Average MC \% & 51.45 & 32.5 & 20.36 & 14.06 & 9.64 & \\
\hline
\end{tabular}

of $\alpha$-pinene, camphene and 1-heptene reached highest around 10-15\% MC (later stage of drying). The concentration of other terpenes reached highest at $20-30 \%$ MC (early-to-mid stage of drying). The total amount of released aldehydes per $\mathrm{m}^{3}$ of wood was $136.39 \mathrm{mg}$, increasing by 6.4 times compared to conventional drying. The amount of $n$-hexanal, $n$-valeraldehyde, acraldehyde and benzaldehyde were all considerably higher, especially $n$-hexanal increased by 9 times (total release reaching $46.636 \mathrm{mg} / \mathrm{m}^{3}$ ) and $n$-valeraldehyde increased by 15 times (total release reaching $42.567 \mathrm{mg} / \mathrm{m}^{3}$ ). The concentration of benzaldehyde was highest around $30 \% \mathrm{MC}$ at the mid-stage of drying, whereas the concentration of other aldehydes reached highest around 15\% MC at the later stage of drying. The amount of released alkenes and propylbenzene were all higher compared to conventional drying, and their total amount was $20.02 \mathrm{mg} / \mathrm{m}^{3}$. The above results clearly showed that for Russian P. sylvestris, the VOCs were released mainly at the later stage of hightemperature drying as indicated by both the amount released and the VOCs concentration.

For both conventional and high-temperature drying, the VOCs released from Russian P. sylvestris were primarily terpene and aldehyde similar to the circumstances for plantation $P$. sylvestris. The terpenes were primarily $\alpha$-pinene and $\beta$-pinene. The aldehydes were primarily n-hexanal, n-valeraldehyde and benzaldehyde. The TVOCs was $385.77 \mathrm{mg} / \mathrm{m}^{3}, 3.5$ times higher than the
TVOCs released during conventional drying (111.18 mg/ $\mathrm{m}^{3}$ ).

\section{Release rate of VOCs}

Figure 6 shows the release rate of aldehyde VOCs for the Russian Pinus sylvestris during conventional and high-temperature drying. During conventional drying (Fig. 6a), the release rate was low and under $1 \mathrm{mg} /\left(\mathrm{m}^{3} \mathrm{~h}\right)$. The release rate of all aldehyde VOCs were highest at the early stage of drying, but because these values were all low, their differences during the entire drying process were small as well. Also the release rate of some aldehyde VOCs was close to zero. Therefore, the release rate of all aldehyde VOCs may be considered as having more or less the same trend.

During high-temperature drying (Fig. 6b), the variation patterns of aldehyde VOCs were approximately similar, gradually increasing at the early stage, slightly decreasing at the mid-stage, then increasing again afterwards, especially the release rate of $n$-hexanal and $n$-valeraldehyde increased considerably at the later stage of drying. For other aldehyde VOCs, the variation in release rate during the entire drying process was small. The variation pattern for the Russian Pinus sylvestris was opposite to that for the plantation Pinus sylvestris. Under high temperature, the Russian Pinus sylvestris was probably more difficult to degrade and also take longer time to degrade than the plantation Pinus sylvestris. 

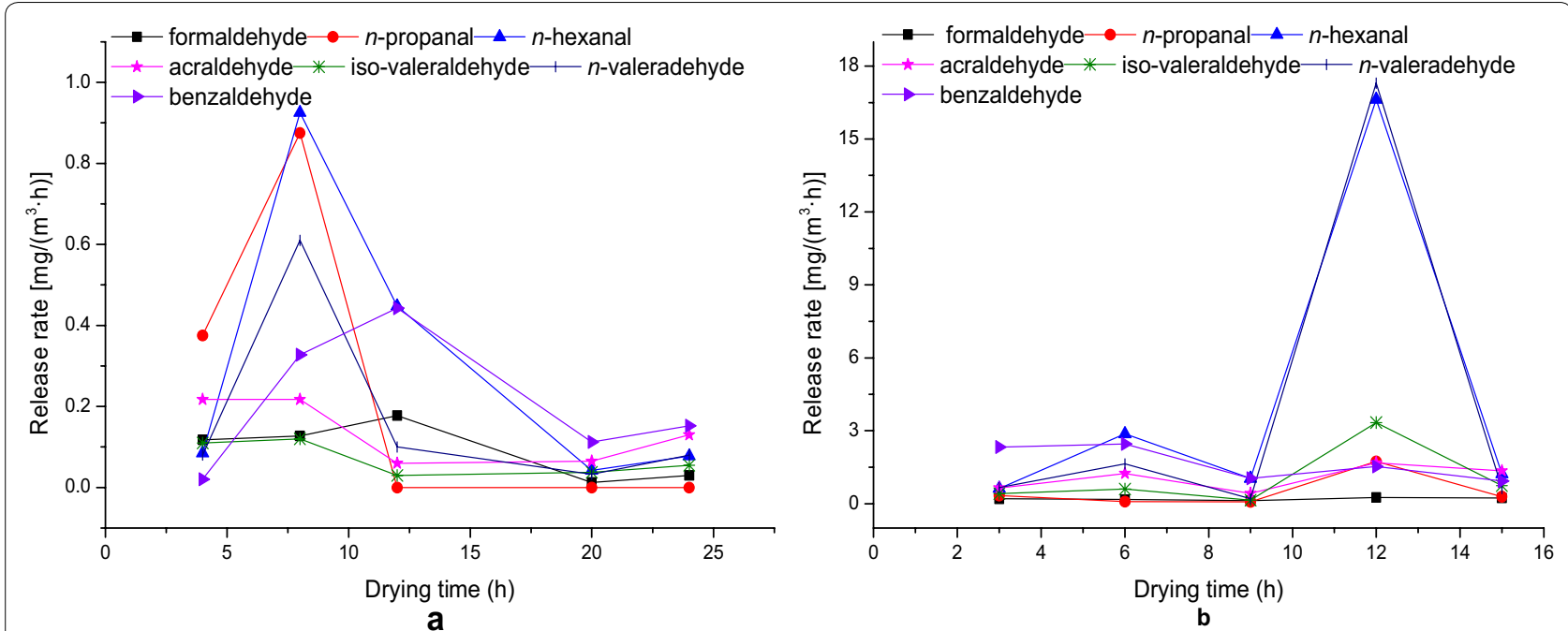

Fig. 6 Variations of release rate of aldehyde VOCs during a conventional drying, and $\mathbf{b}$ high-temperature drying for the Russian Pinus sylvestris

Figure 7 shows the release rate of other VOCs for the Russian P. sylvestris during conventional and high-temperature drying. During conventional drying (Fig. 7a), the release rate of $\alpha$-pinene increased quickly during the first $8 \mathrm{~h}$ and reached $10.72 \mathrm{mg} /\left(\mathrm{m}^{3} \mathrm{~h}\right)$, then decreased during the rest hours of drying. The release rates of all other terpene VOCs were very small and slightly varied during the complete drying process.

During high-temperature drying (Fig. 7b), the release rate of $\alpha$-pinene and limonene gradually increased during the first $6 \mathrm{~h}$, then decreased, then the release rate of $\alpha$-pinene had a large increase at the later stage of drying and reached $36.19 \mathrm{mg} /\left(\mathrm{m}^{3} \mathrm{~h}\right)$. The release rate of $\beta$-pinene increased gradually during the first $12 \mathrm{~h}$ and reached the maximum of $5.88 \mathrm{mg} /\left(\mathrm{m}^{3} \mathrm{~h}\right)$ at the mid-stage. The drying rate of 1-heptene had a considerable increase at the later stage, but was small and varied little at the other stages of drying.

Figure 8 shows variation of release rate of the total amount of VOCs (TVOCs) during conventional and high-temperature drying of the Russian Pinus sylvestris. During conventional drying, the release rate of TVOCs increased quickly at the early stage (the first $6 \mathrm{~h}$ ), then decreased until remaining stable close to the end of drying. During high-temperature drying, the release rate of TVOCs gradually increased at the early stage, then
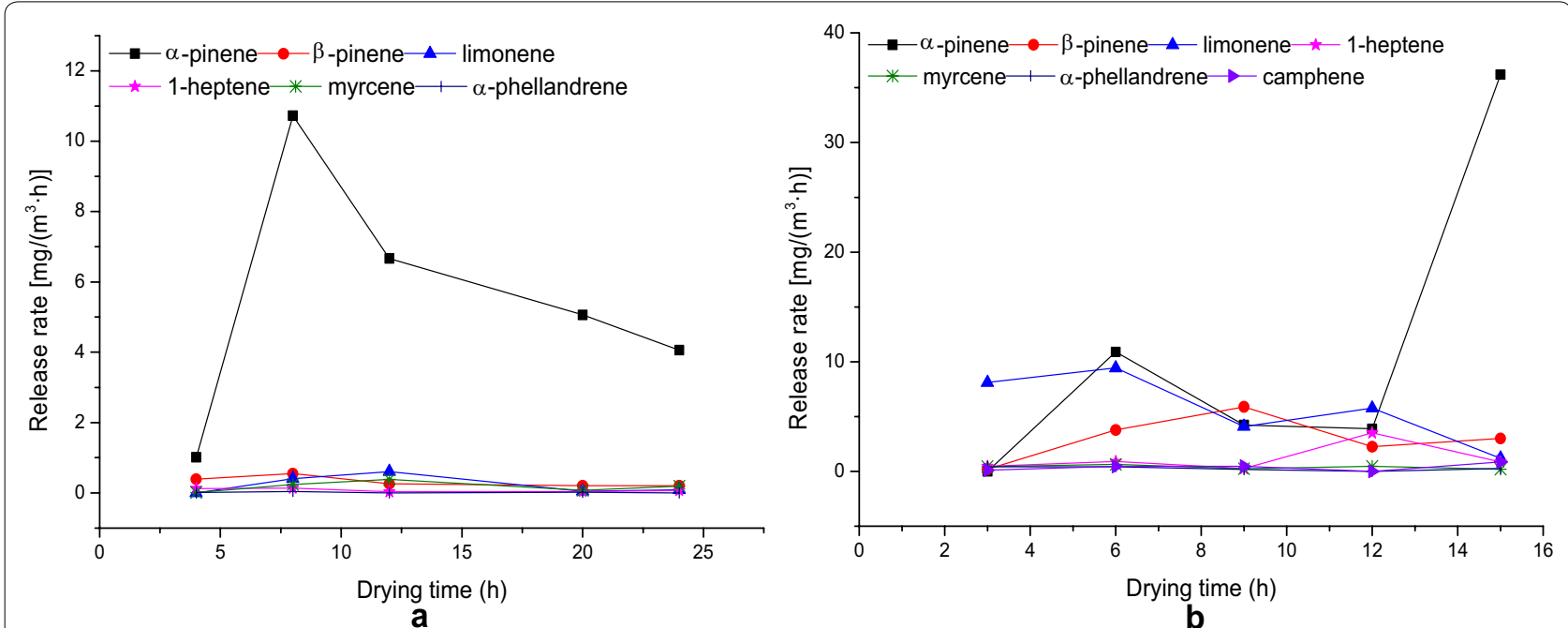

Fig. 7 Variations of release rate of terpene VOCs during a conventional drying, and $\mathbf{b}$ high-temperature drying for the Russian Pinus sylvestris 
started to decrease, with a very large increase subsequently between the 9th and 12th hour, followed by a decrease at the later stage of drying. The above results showed that during conventional drying, the VOCs were released mainly at the early stage. During high-temperature drying, the VOCs were mainly released at the later stage.

\section{Comparison of the amount of primary VOCs between plantation Pinus sylvestris and Russian Pinus sylvestris}

Table 6 is a summary of the total amount of primary VOCs released per $\mathrm{m}^{3}$ of wood during conventional and high-temperature drying for both plantation Pinus sylvestris and Russian Pinus sylvestris. These values corresponded to $8-10 \% \mathrm{MC}$, and have been presented in several previous tables.

Table 6 shows that during the entire process of conventional and high-temperature drying, more aldehyde VOCs, especially $n$-propanal and $n$-hexanal, were released from the plantation Pinus sylvestris than from the Russian Pinus sylvestris. Very large amount of terpene VOCs, in particular $\alpha$-pinene and $\beta$-pinene, were also released from the plantation Pinus sylvestris and were much greater than those from the Russian Pinus sylvestris. However, the amount of limonene and 1-heptene released from the plantation Pinus sylvestris was less than those from the Russian Pinus sylvestris. Benzene VOCs was detected from the plantation Pinus sylvestris, but not obtained from the Russian Pinus sylvestris.

During conventional drying, the amount of aldehyde VOCs (except benzaldehyde) released from the plantation Pinus sylvestris was higher than those from the Russian Pinus sylvestris. The released $n$-propanal, $n$-hexanal and $n$-valeraldehyde were 7.36, 5.97 and 10.66 times as much as those from the Russian Pinus sylvestris, respectively. However, benzaldehyde released from the Russian Pinus sylvestris was 2.97 times as much as that from the plantation Pinus sylvestris.

During high-temperature drying, the amount of aldehydes, $\alpha$-pinene, $\beta$-pinene, camphene, and myrcene released from the plantation Pinus sylvestris were higher than those released from the Russian Pinus sylvestris. The $n$-propanal and $n$-hexanal released from the plantation Pinus sylvestris were 12.93 and 5.72 times as much as those from the Russian Pinus sylvestris, respectively. The $n$-valeraldehyde and benzaldehyde released from the plantation Pinus sylvestris were 1.11 and 1.19 times as much as those from the Russian Pinus sylvestris, respectively. The $\alpha$-pinene, $\beta$-pinene, camphene and myrcene released from the plantation material were 5.42, 3.38, 7.55 and 20.99 times as much as those from the Russian Pinus sylvestris, respectively. More limonene and 1-heptene were released from the Russian Pinus sylvestris, which were 1.62 and 1.85 times as much as those from the plantation P. sylvestris, respectively.
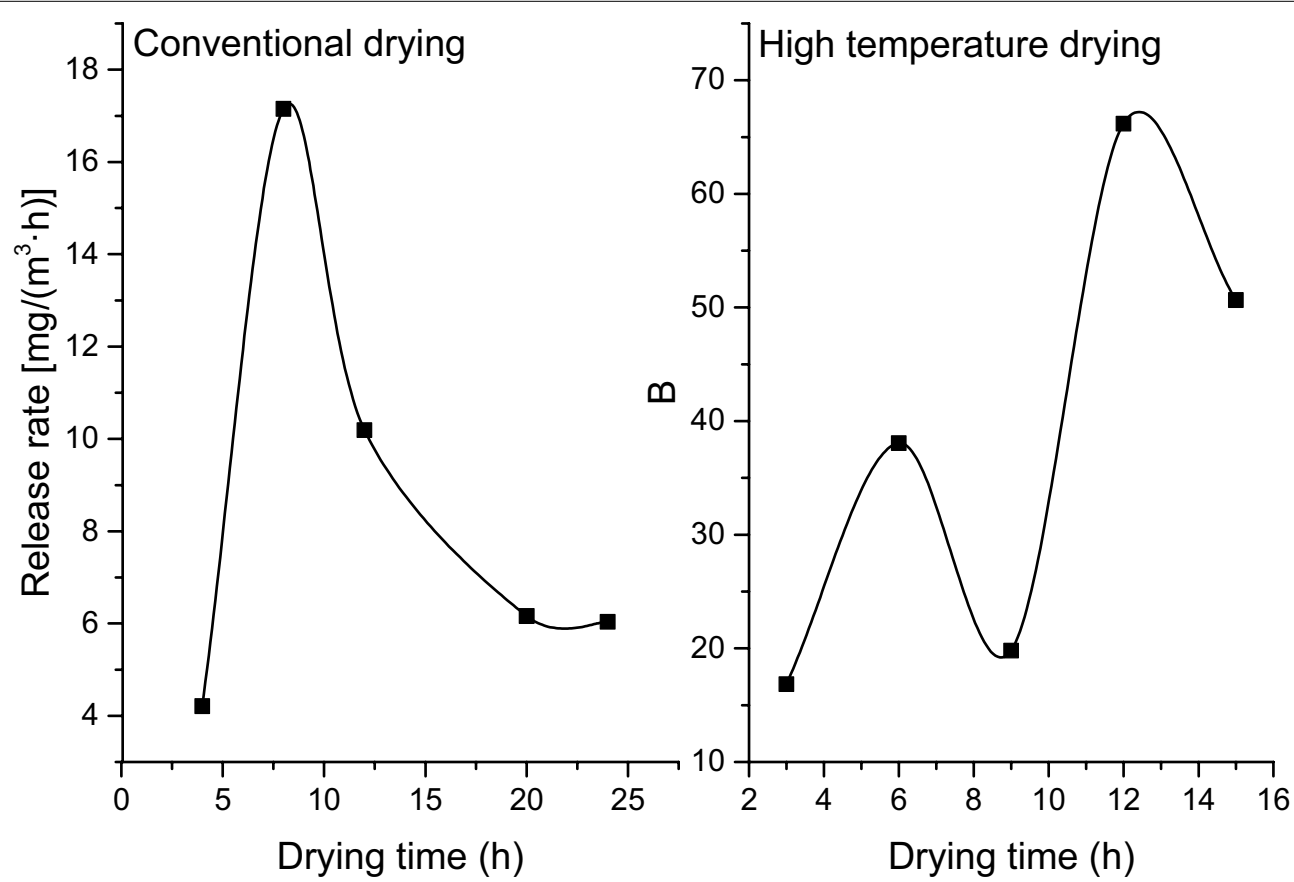

Fig. 8 Variation of release rate of TVOCs during conventional and high-temperature drying of the Russian P. sylvestris 
Table 6 Total amount of primary VOCs released per $\mathrm{m}^{3}$ of wood during conventional and high-temperature drying for plantation Pinus sylvestris and Russian Pinus sylvestris

\begin{tabular}{|c|c|c|c|c|}
\hline \multirow[t]{3}{*}{ VOCs } & \multicolumn{4}{|c|}{ Amount of VOCs ( $\mathrm{mg} / \mathrm{m}^{3}$ of wood) } \\
\hline & \multicolumn{2}{|c|}{ Plantation Pinus sylvestris } & \multicolumn{2}{|c|}{ Russian Pinus sylvestris } \\
\hline & Conventional & High temperature & Conventional & $\begin{array}{l}\text { High } \\
\text { temperature }\end{array}$ \\
\hline n-Propanal & 25.59 & 68 & 3.48 & 5.26 \\
\hline n-Hexanal & 26.86 & 267.1 & 4.49 & 46.64 \\
\hline$n$-Valeraldehyde & 27.65 & 47.3 & 2.59 & 42.57 \\
\hline Benzaldehyde & 1.09 & 20.42 & 3.24 & 17.28 \\
\hline a-Pinene & 100.24 & 623.83 & 90.5 & 115 \\
\hline$\beta$-Pinene & 2.48 & 106.68 & 5 & 31.49 \\
\hline Camphene & 3.46 & 30.04 & - & 3.97 \\
\hline Myrcene & 1.2 & 87.01 & 2.68 & 4.14 \\
\hline Limonene & 6.41 & 36.63 & 3.32 & 59.63 \\
\hline 1-Heptene & 4.05 & 6.71 & 1.22 & 12.47 \\
\hline Benzene & - & 84.99 & - & - \\
\hline Propylbenzene & 0.49 & 5.46 & - & - \\
\hline
\end{tabular}

Overall, the VOCs released from the plantation Pinus sylvestris were much greater than those from the Russian Pinus sylvestris. The difference of VOCs content between the two is mainly due to the difference of tree age and growth conditions, which leads to the difference of extraction amount and material quality.

\section{Conclusions}

1. From the plantation Pinus sylvestris, large amount of aldehyde, terpene, alkane and benzene VOCs were released during drying. The aldehyde VOCs were primarily $n$-propanal, $n$-hexanal and $n$-valeraldehyde. The terpene VOCs were primarily $\alpha$-pinene, $\beta$-pinene and myrcene. Large amounts of benzene VOCs were released during high-temperature drying.

2. From the Russian Pinus sylvestris, the primary VOCs released during drying were terpene VOCs (in particular $\alpha$-pinene and limonene), followed by aldehyde VOCs (in particular $n$-hexanal, $n$-valeraldehyde and benzaldehyde). No benzene was detected.

3. For the plantation Pinus sylvestris, the VOCs released during conventional drying primarily occurred at the later stage, but the VOCs released during hightemperature drying primarily occurred at the early stage. For the Russian Pinus sylvestris, the amount of released VOCs and the release rate were very small during conventional drying. During high-temperature drying, the VOCs were released primarily at the later stage.
4. Overall, the VOCs released from the plantation Pinus sylvestris were much higher than those from the Russian Pinus sylvestris. High-temperature drying resulted in considerable increases in both the amount of VOCs and the release rate.

Abbreviations

VOCs: Volatile organic compounds; TVOCs: Total volatile organic compounds.

Acknowledgements

This study was supported by funding from the National key research and development plan (2016YFD06007012, 2017YFD0600202). We also thank the Fuyuan company (in Hohhot) for the analysis of the VOCs specimens.

Authors' contributions

$Y S, X Z, Q H, X W$ designed the research study; $Y S$ and $X W$ analyzed the experimental data; YS wrote the paper. ZW, LY, YW, JY, HD, XW assisted in proofreading the articles; JY and ZC providing language help. All authors supervised the work and edited the manuscript. All authors read and approved the final manuscript.

\section{Funding}

This work was supported by funding from the National key research and development plan (2016YFD06007012, 2017YFD0600202).

\section{Availability of data and materials}

All data generated or analyzed during this study are included in this published article.

Consent for publication

Not applicable for this study.

\section{Competing interests}

The authors declare that they have no competing interests. 


\section{Author details}

${ }^{1}$ College of Material Science and Art Design, Inner Mongolia Agricultural University, Hohhot 010018, China. ${ }^{2}$ College of Science, Inner Mongolia Agricultural University, Hohhot 010018, China. ${ }^{3}$ Department of Sustainable Biomaterials, Virginia Tech University, Blacksburg, VA 24061, USA. ${ }^{4}$ Melbourne, Australia.

Received: 30 December 2019 Accepted: 1 May 2020

Published online: 12 May 2020

\section{References}

1. Granstrom K (2003) Emissions of monoterpenes and VOCs during drying of sawdust in a spouted bed. For Prod J 53(10):48-55

2. McDonald AG, Dare PH, Gifford JS, Steward D, Riley S (2002) Assessment of air emissions industrial kiln drying of pinus radiate wood. Holz Roh Werkst 60(3):181-190

3. Marć M, Śmiełowska M, Namieśnik J, Zabiegała B (2018) Indoor air quality of everyday use spaces dedicated to specific purposes-a review. Environ Sci Pollut Res 25:2065-2082

4. Chen Y, Li XH, Zhu TL, Han YJ, Lv D (2017) PM2.5-bound PAHs in three indoor and one outdoor air in Beijing: concentration, source and health risk assessment. Sci Total Environ 586:255-264

5. Soto GL, Ashley WJ, Bregg S, Walier D, LeBouf R, Hopke PK, Rossner A (2015) VOCs emissions from multiple wood pellet types and concentrations in indoor air. Energy Fuels 29:6485-6493

6. Jiang C, Li D, Zhang P, Li JG, Wang J, Yu JG (2017) Formaldehyde and volatile organic compound (VOC) emissions from particleboard: identification of odorous compounds and effects of heat treatment. Build Environ 117:118-126

7. Conners TE, Yan H, Banerjee S (2002) Mechanism of VOC release from high-temperature southern pine lumber drying. Wood Fiber Sci 34(4):666-669

8. Milota Michael R (2003) HAP and VOC emission from white fir lumber dried at high and conventional temperatures. For Prod J 53(3):60-64

9. Hyttinen M, Masalin WM, Kalliokoski P, Pasanen P (2010) Comparison of VOC emissions between air-dried and heat-treated Norway spruce (Picea abies), Scots pine (Pinus sylvestris) and European aspen (Populus tremula) wood. Atmospheric Environ 44(38):5028-5033

10. Shmulsky R, Ingram LL Jr (2000) Empirical prediction of VOC emissions from drying southern yellow pine lumber. For Prod J 50(6):61-63

11. Ling $L$ (2011) Release and evaluation of volatile organic compounds in wood and its products. Science Press in Beijing (In Chinese)

12. Otwell LP, Hittmeier ME, Usha $H$ (2000) HAPs release from wood drying. Environ Sci Technol 34(11):2280-2283
13. Banerjee S, Su W, Wild MP, Otwell LP, Hittmeier ME, Nichols KM (2000) Wet line extension reduce VOC from softwood drying. Environ Sci Technol 34(11):1303-1307

14. Bengtsson P, Sanati M(2004) Measure and mathematical modeling of the hydrocarbon emission from wood drying. In: Proceedings of the 14th international drying symposium, Sao Paulo, Brazil. 22-25 August 2004, pp 1352-1359

15. Finn E, Ralph MN (2000) Monoterpenes in scots pine and Norway spruces and their emission during kiln drying. Holzforschung 54(5):449-456

16. Ingram LL Jr, Shmulsky R, Taylor FW, Dalton AT, Templeton MC (2000) The measurement of volatile organic emission from drying organic emission from drying southern pine lumber in a laboratory-scale kiln. For Prod J 50(4):91-94

17. Conners TE, Ingram LL, Su W, Yan H, Banerjee S, Dalton AT, Templeton MC (2001) Seasonal variation of southern pine terpenes. For Prod J 51(6):89-94

18. Shmulsky R (2000) End-grain influence on VOC emission from kiln-drying loblolly pine. For Prod J 50(5):21-23

19. Wen D, Liping N, Yan X, Hao S, Tianshi W, Rongmiao A (2017) Essential oils extracted from Phoebe hui Chengex Yang: chemical constituents, antitumor and antibacterial activities, and potential use as a species identifier. J Wood Chem Technol 37:201-210

20. Pétrissans A, Younsi R, Chaouch M, Gérardin P, Pétrissans M (2014) Wood thermo degradation: experimental analysis and modeling of mass loss kinetics. Maderas Ciencia y Tecnología 16(2):133-148

21. Mburu F, Dumarçay S, Huber F, Petrissans M, Géraadin P (2007) Evaluation of thermally modified Grevillea robusta heartwood as an alternative to shortage of wood resource in Kenya: characterization of physicochemical properties and improvement of bio-resistance. Bioresour Technol 98(18):3478-3486

22. Wikberg H, Maunu SL, Sundholm F, Jämsä S, Viitaniemi P (2002) Magnetic resonance studies of thermally modified wood. Holzforschung 56(6):648-654

23. Tjeerdsma B, Militz H (2005) Chemical changes in hydrothermal treated wood: FTIR analysis of combined hydrothermal and dry heat-treated wood. Holz Roh Werkst 63(2):102-111

24. Esteves B, Videira R, Pereira H (2011) Chemistry and ecotoxicity of heattreated pine wood extractives. Wood Sci Technol 45(4):661-676

\section{Publisher's Note}

Springer Nature remains neutral with regard to jurisdictional claims in published maps and institutional affiliations.

\section{Submit your manuscript to a SpringerOpen ${ }^{\circ}$ journal and benefit from:}

- Convenient online submission

- Rigorous peer review

- Open access: articles freely available online

- High visibility within the field

Retaining the copyright to your article

Submit your next manuscript at springeropen.com 